\title{
Innovation of Surgical Correction of Rectal Prolapse in Sows
}

\author{
Svatopluk Čech, Zbyněk Jan, Eva Malá, Radovan Doležel \\ Ruminant Clinic, Faculty of Veterinary Medicine, \\ University of Veterinary and Pharmaceutical Sciences, Brno, Czech Republic \\ Received December 29, 2008 \\ Accepted June 30, 2009
}

\begin{abstract}
The aim of the work was to describe an alternative method of treatment of prolapsed rectum in the sows. This approach was used to treat rectal prolapse in four affected sows. A $23.5 \mathrm{~cm}$ long Gerlach's needle was used for sewing a circular suture around the base of prolapsed rectum. The horizontal U-suture was performed with a synthetic absorbable surgical fibre. Two fibres 25-30 $\mathrm{cm}$ long were placed into the needle eye, the needle was inserted under finger control into the rectal lumen and the prolapsed tissue was penetrated from the inside to the outside. Both ends of the first fibre were grasped by haemostatic forceps and fixed for the last stitch and the inner end of the second fibre was placed into the needle eye with the third fibre. Rectal tissue was penetrated in the same manner at the distance of $2-3 \mathrm{~cm}$ from the place of the first penetration. The first U-stitch was made by tying both ends of the second fibre after the needle removal. The inner end of the third fibre was placed into the needle eye with the fourth fibre and the procedure was repeated around the whole prolapse until the first fibre was reached and used for the last stitch. The prolapsed tissue was excised by a blade at the distance of approximately $2 \mathrm{~cm}$ from the suture. There was no haemorrhage due to ligation of the tissue. After placing the simple continuous catgut suture around the rectum, a spontaneous retraction of the stump occurred, and the purse-string suture was not required. This method is applicable in practice in sows suffering from large, oedematous and hard prolapse when simple reposition or use of another surgical correction is impossible. In addition, the method may be used also in other large animal species.
\end{abstract}

Swine, pig, rectum, amputation, Gerlach's needle

Although prolapse of the rectum can occur in all species of domestic animals (pigs, ruminants, horses, carnivores) (Šutta and Orság 1986; Anderson and Meisner 2008) the disease is most common in the swine. The highest incidence of rectal prolapse is described in young pigs between 6 and 16 weeks of age and varies from $0.7 \%-15 \%$. The incidence in sows varies between $0.5 \%$ and $1 \%$ and two-thirds of the cases occur around the time of parturition (Smith and Straw 2006) or within the first two weeks of lactation (Borobia-Belsué 2006). Prolapse of the rectum in sows sometimes occurs together with vaginal prolapse $(21.2 \%)$ and vesical flexion $(31.2 \%)$ at the time of parturition (Schulz and Bostedt 1995).

Rectal prolapse in pigs occurs if support ad fixation mechanisms (fascia, muscles, ligaments) are overcome by pressure (straining caused by constipation, diarrhoea, coughing) or the support tissues are weakened (fat or tumour infiltration, genetics, certain drugs or oedema due to mycotoxins, particularly zearalenone) (Smith and Straw 2006; Osweiler 2006). An important cause of rectal prolapse in sows is the abdominal strain during farrowing (Smith and Straw 2006) and flexibility and oedema of the connective tissue around the rectum and perineal area during lactation (Borobia-Belsué 2006).

The diagnosis of rectal prolapse is easy, but care should be taken that the prolapse does not involve other organs (Jean and Anderson 2006). Sometimes temporary protrusion of a portion of the rectal mucosa occurs during defecation or coughing, but usually the length of the protruding rectal mucosa varies from about 10 to $13 \mathrm{~cm}$ (Smith and Straw 2006). Cannibalism in sows housed in groups or biting of prolapsed rectum in sows fixed in the farrowing crate

Address for correspondence:

MVDr. S. Čech, Ph.D.

Clinic of Diseases of Ruminants, Faculty of Veterinary Medicine

University of Veterinary and Pharmaceutical Sciences

Palackého 1-3, 61242 Brno, Czech Republic

\author{
Phone: +420541562317 \\ Fax: $\quad+420541562332$ \\ E-mail: cechs@vfu.cz \\ http://www.vfu.cz/acta-vet/actavet.htm
}


by piglets can cause tissue damage and haemorrhaging (Borobia-Belsué 2006). Thus the prolapsed rectum can be found in various conditions (fresh undamaged, oedematous, ruptured, lacerated, infected, necrotic) (Filipov 1981). The disease can therefore be life-threatening and immediate treatment is required (Borobia-Belsué 2006).

The correction of rectal prolapse is the most commonly performed gastrointestinal surgical procedure in swine (Smith and Straw 2006). Various techniques for the replacement of rectal prolapse have been described. The animals were restrained and put under general anaesthesia (Vonderfecht 1978) or local anaesthesia (Filipov 1981; Borobia-Belsué 2006). The usual procedure for correction of rectal prolapse is its reposition and application of a purse-string suture (Jean and Anderson 2006; Borobia-Belsué 2006). If the rectal mucosa is not viable or is lacerated, surgical correction of prolapse can be approached (Vonderfecht 1978). The simplest method was carried out only by pressure necrosis caused by ligation of the prolapse around a plastic tube inside the prolapse (Douglas 1985; Beilage and Beilage 1994). A common surgical procedure is to fix the prolapse by sticking two needles at right angles in the rectum and a soft tube previously inserted into the prolapse. The prolapse is dissected and the stump is circumscribed with a simple continuous stitch without a purse-string suture of the anus (Vonderfecht 1978).

Several similar procedures with few differences have been described. A circular incision of the mucosa with a subsequent blunt dissection of the connective tissue without incision of the submucosa and muscularis was described by Merritt (1964). Kjar (1976) described successive dissection of the prolapsed rectum with an inside-out continuous catgut suture; fixation of the prolapse with three U-stitches without subsequent suture was described by Filipov (1981). Sometimes natural recovery is possible but rectal stricture may develop (Smith 1981).

Prolapsed rectum in postpartum sow is sometimes very large, oedematous and hard, particularly in older prolapses. In such cases, simple reposition is impossible and the use of above mentioned surgical correction is questionable. Therefore, our aim was to develop an alternative method of surgical correction of large and long-lasting prolapses of rectum in sows.

\section{Materials and Methods}

The below described procedure was used in four lactating sows suffering from prolapsed rectum. The sows were after $2^{\text {nd }}$ to $5^{\text {th }}$ parturition and the body condition scores were between 3 and 3.5 . The rectal prolapses occurred 4-10 days after normal parturition and the sows were fixed in farrowing crates. The diameter and length of the prolapsed rectum was $8-12 \mathrm{~cm}$ and $10-15 \mathrm{~cm}$. The mucosa was haemorrhagic, oedematous and damaged (Plate X, Fig. 1).

The sows were treated by azaperon ( $4 \mathrm{mg} / \mathrm{kg}$ i.m., Stresnil inj. ad us. vet.) and 10-15 min later by ketamine $(10 \mathrm{mg} / \mathrm{kg}$ i.v., Narketan $10 \mathrm{inj}$. ad us. vet.). The sows were fixed in a lateral position with elevated rump. The area of prolapse was cleansed and debris was removed. A $23.5 \mathrm{~cm}$ long Gerlach's needle was used for making a circular suture around the base of the prolapsed rectum. Horizontal U-stitches were performed using synthetic absorbable surgical suture (Surgicryl PGA, EP 6). Two fibres 25-30 cm long were placed into the needle eye (Fig. 2) and were bound around the tip of the needle. The needle was inserted under finger control into the rectal lumen and rectal tissue was penetrated approximately $1 \mathrm{~cm}$ posterior to the anal orifice from the inside to the outside of the prolapsed rectum (Scheme 1, Fig. 3). Fibres were loosened from the needle eye and the needle was removed. Both ends of the first fibre were grasped by haemostatic forceps and fixed for the last stitch and the inner end of the second fibre was placed into the needle eye with the third fibre. Rectal tissue was penetrated in the same manner at the distance of $2-3 \mathrm{~cm}$ from the place of the first penetration (Scheme 2). Both ends of the second fibre were firmly tied after the needle removal - the first U-stitch (Fig. 4). The inner end of the third fibre was placed into the needle eye with the fourth fibre (Scheme 3), etc. The procedure was repeated around the whole prolapse until the first fibre was reached and used for the last stitch. The fibres of the stitches at twelve, three and nine o'clock position were left as a fixation and the others were cut. The prolapsed tissue was excised by the blade at a distance of approximately $2 \mathrm{~cm}$ from the suture (Figs 5, 6, Plate XI, Fig. 7). Haemorrhage did not occur because all of the tissue had been ligated. The stump was held by three fixation fibres and simple continuous suture (Catgut No 5) was sewn circularly around the rectum (Figs 8, 9). The fixation fibres were cut off (Fig. 10) after treatment of the stump by oxytetracycline pulvis (Aureozasyp $2 \%$ plv. ad us. vet.). The stump retracted spontaneously and purse-string suture was not required (Fig. 11). 

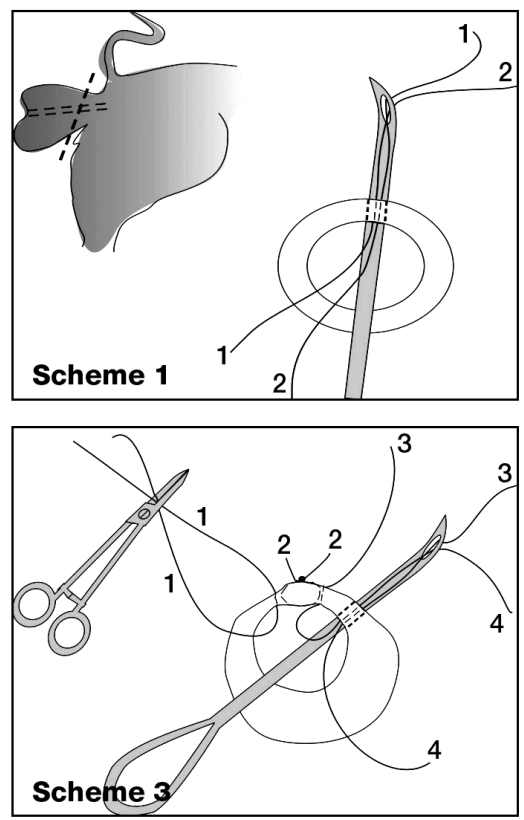

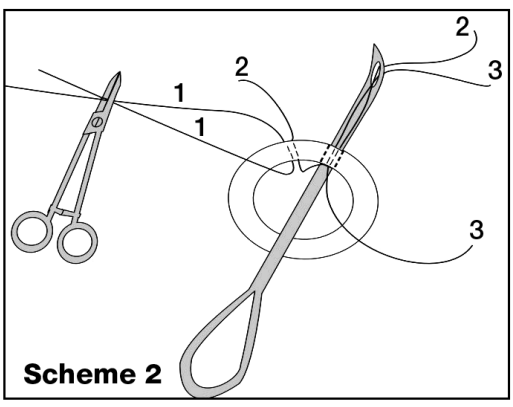

Scheme 1. Scheme of the prolapse and the first perforation.

Scheme 2. The second perforation.

Scheme 3 . The third perforation. The first stitch finished.

Following surgery, the sows were given natrium phenoxymethylpropionatum (1.5 g pro toto i.m., Hepagen inj. ad us. vet.) and metamizol ( $25 \mathrm{mg} / \mathrm{kg}$ i.m., Vetalgin inj. ad us. vet). Broad-spectrum antibiotic treatment (penicillin $8 \mathrm{mg} / \mathrm{kg}$ i.m., streptomycin $10 \mathrm{mg} / \mathrm{kg}$ i.m., Norostrep inj. ad us. vet.) was administered for five consecutive days. The sows were given normal feed with the addition of cooking oil (100 ml/day p.o.) to support production of soft faeces.

\section{Results and Discussion}

The usual procedure for correction of rectal prolapse is its reduction by a gentle massage, reposition and retention by application of a purse-string suture pattern using appropriate tape or fibre (Jean and Anderson 2006; Borobia-Belsué 2006). A one/two-fingers opening should be left when tying the purse string (Jean and Anderson 2006; Borobia-Belsué 2006) according to animal size. However, surgical correction is often necessary due to various damages of the prolapse (large oedema, laceration, rupture, infection, necrosis).

The simplest method of rectal prolapse amputation was carried out using a $5-10 \mathrm{~cm}$ piece of plastic hose or corrugated helical tube inside and ligation around the prolapse. Pressure necrosis due to ligation leads to amputation of the prolapse (Douglas 1985; Beilage and Beilage 1994). However, this method is not suitable in terms of welfare, and in addition, it can be performed only in individual pens because of cannibalism. A common surgical procedure represents insertion of a soft tube of appropriate size into the lumen of the rectum and fixation of the tube in the rectum by inserting two needles through the rectum and tube at right angles. Dissection of the prolapse should begin posterior as far as possible, however, it must be done in healthy tissue. Dissection begins on the dorsal surface of the prolapsed tissue and continues in a clockwise direction until the rectum is completely dissected. The dorsal artery of the rectum must be grasped with haemostatic forceps and ligated. The amputated stump is circumscribed with a simple continuous stitch. The rectum automatically retracts into place after removal of the needles and tube. Pursestring suture is not required (Vonderfecht 1978).

Several similar procedures with a few differences have been developed. A circular 
incision of the mucosa with subsequent blunt dissection of connective tissue without incision of the submucosa and muscularis has been described. The remaining portion of prolapsed intestine was returned through anal opening after removal of mucosa without its suturing. Purse-string suture was sewn in the anus and removed after $48 \mathrm{~h}$ (Merritt 1964). Successive dissection of the prolapsed rectum starting $1 \mathrm{~cm}$ from the mucocutaneous border was described by Kjar (1976). A rectal lymph node and accompanying blood vessels on the dorsal surface of the inner wall were ligated. When the inner wall was completely freed of surrounding tissue, forceps were applied at 2 or 3 places and the prolapsed rectum was amputated. An inside-out continuous catgut suture with stitches spaced about $6 \mathrm{~mm}$ apart was used without aftercare. Surgical treatment on a standing restrained animal described Filipov (1981). A local circular block was made at the anal ring and local anaesthetic was also injected submucosally into the prolapsed gut. A fixation of prolapse was made with three U-stitches at twelve, three and nine o'clock position and entire circumference of the prolapsing of the gut was cut $0.5 \mathrm{~cm}$ posterior to the anal orifice without subsequent suture. Sometimes no surgical treatment is carried out, and the prolapse is simply left to resolve naturally in 10-14 days. However, this practice is not good welfare (Smith and Straw 2006) and the pig may develop a complete or partial rectal stricture (Smith 1981). However, all the above described procedures are suitable for correction of a prolapse in growing pigs and only incomplete ligation of arteries is applied before the incision ( $\mathrm{Kjar}$ 1976; Vonderfecht 1978; Filipov 1981).

Rectal prolapse in sows is larger than in growing pigs and reposition is more difficult namely in long lasting prolapses with pathological changes of the rectal wall. In such cases surgical amputation is necessary. In addition, there are larger blood vessels in sows than in growing pigs and therefore total ligature of the base of the prolapsed rectum is required before amputation to prevent haemorrhaging. Therefore, we tried to develop a new procedure that could be suitable for those cases. The Gerlach's needle modified by Bühner is commonly used for treatment of prolapsed vagina in cows (Grunert 1982). The size of this needle is sufficient to reach the base of the prolapsed rectum from the inside. Two fibres are passed through each needle perforation and all tissue without breaks is ligated. Thus the ligature prevents any bleeding. Simple continuous suture after the cutting of the prolapsed tissue closes the surgical wound completely. In spite of local anaesthesia by infiltration of the anal ring with $2 \%$ lidocaine being described at surgical correction of the rectal prolapse (Filipov 1981) we prefer general anaesthesia according with Vonderfecht (1978). The course of treatment is quieter and this type of anaesthesia is better in terms of animal welfare.

Despite the fact that our amputation technique is more time consuming, it is practicable, safe and successful even in cases where the prolapse is large, very oedematous, hard and/or damaged. The recovery of the surgical wound was completed in a short time and any signs of pathological condition and treatment disappeared within 2 days after treatment in all of the animals in our trial (Plate XI, Fig. 12). The sows finished lactation successfully and were inseminated after their piglets were weaned. Our results must be evaluated carefully as the experimental animals are few. However, this condition is rather scarce and it is not easy to find comparable types of rectal prolapse that were included in our trial. Nevertheless, based on the positive response to treatment in all animals we consider this method to be applicable in practice. In addition, it can be presupposed that the method is useful also in other large animal species.

\section{Inovace chirurgického ošetření prolapsu rekta u prasnic}

Cílem práce bylo popsat alternativní metodu ošetření prolapsu rekta u prasnic. Cirkulární sutura horizontálními U-stehy okolo báze výhřezu byla provedena za použití Gerlachovy jehly dlouhé $23,5 \mathrm{~cm}$. Dvě vlákna ze syntetického vstřebatelného materiálu o délce 
25-30 cm byla navlečena do ucha jehly, jehla byla pod kontrolou prstu zavedena do lumina rekta a vyhřezlá tkáň byla probodnuta zevnitř ven asi $1 \mathrm{~cm}$ od hranice kůže. Oba konce prvního vlákna byly zachyceny do chirurgických klíštěk a fixovány pro poslední steh. Vnitřní konec druhého vlákna byl navlečen do jehly společně s třetím vláknem. Tkán̆ rekta byla probodnuta obdobně ve vzdálenosti $2-3 \mathrm{~cm}$ od první penetrace. První U-steh byl dokončen pevným dotažením obou konců druhého vlákna. Vnitřní konec třetího vlákna byl navlečen do jehly společně se čtvrtým vláknem a postup byl opakován okolo celého prolapsu až bylo dosaženo první vlákno, ze kterého byl vytvořen poslední steh. Výhřez byl amputován skalpelem ve vzdálenosti asi $2 \mathrm{~cm}$ od sutury, nedošlo k žádnému krvácení, protože veškerá tkáň byla kompletně ligována. Sutura byla dokončena jednoduchým cirkulárním stehem. Po uvolnění fixace došlo ke spontánní retrakci pahýlu, sutura anu míškovým stehem nebyla nutná.

Po uvolnění fixace došlo ke spontánní retrakci pahýlu, sutura anu míškovým stehem nebyla nutná. Metoda je použitelná zejména v př́ípadech velikých edematózních nebo poškozených výhřezů rekta, kdy jiné ošetření by bylo obtížně uskutečnitelné. Stejný postup může být proveden i u dalších druhů velkých zvírat.

\section{Acknowledgement}

The study was supported by the grant MSM Czech Rep. No. 6215712403.

\section{References}

Anderson DE, Miesner MD 2008: Rectal prolapse. Vet Clin Food Anim 24: 403-408

Borobia-Belsué J 2006: Replacement of rectal prolapse in sows. Vet Rec 158: 380

Beilage EG, Beilage GT 1994: The surgical treatment of intestinal prolapse (prolapsus recti) in fattening swine under practice conditions. Dtsch Tierarztl Wochenschr 101: 383-387

Douglas RGA 1985: A simple method for correcting rectal prolapse in pigs. Vet Rec 117: 129

Filipov MM 1981: A surgical technique for excision of prolapsed rectum in swine. Can Vet J 22: 362

Greenwood J 1989: Treatment of bladder retroversion with rectal prolapse in a sow. Vet Rec 125: 405-406

Grunert E 1982: Gynäkologische Operationen. In: Grunert E, Berchtold M: Fertilitätstörungen beim weiblichen Rind. Verlag Paul Parey 1982: 476-492

Jean GS, Anderson DE 2006: Anesthesia and Surgical Procedures in Swine. In: Straw BE, Zimmerman JJ, D’Allaire S, Taylor DJ: Diseases of Swine. Blackwell Publishing 2006: 1107-1129

Kjar HA 1976: Amputation of prolapsed rectum in young pigs. J Am Vet Med Assoc 168: 229-230

Merritt AM 1964: Treatment for prolapsed rectum in the pig. J Am Vet Med Assoc 145: 790-792

Osweiler GD 2006: Occurrence of mycotoxins in grains and feeds. In: Straw B E, Zimmerman J, J, D’Allaire S, Taylor D J: Diseases of Swine. Blackwell Publishing 2006: 915-929

Schulz S, Bostedt H 1995: Vesical flexion and vaginal prolapse of sows as an obstetrical problem. Tierarztl Prax 23: 139-147

Smith WJ, Straw BE 2006: Prolapses. In: Straw BE, Zimmerman JJ, D’Allaire S, Taylor DJ: Diseases of Swine. Blackwell Publishing, pp. 965-969

Smith WJ 1981: Rectal prolapse in swine. Pig Vet Soc Proc 7: 68-72

Šutta J, Orság A 1986: Speciálná operačná chirurgia. In Veterinárna chirurgia. Bratislava; Príroda/ Praha; SZN, pp. 400-402

Vonderfecht HE 1978: Amputation of rectal prolapse in pigs. Vet Med/Small Anim Clin 73: 201-206 

Plate X

Čech S. et al.: Innovation of Surgical ... pp. 121-126
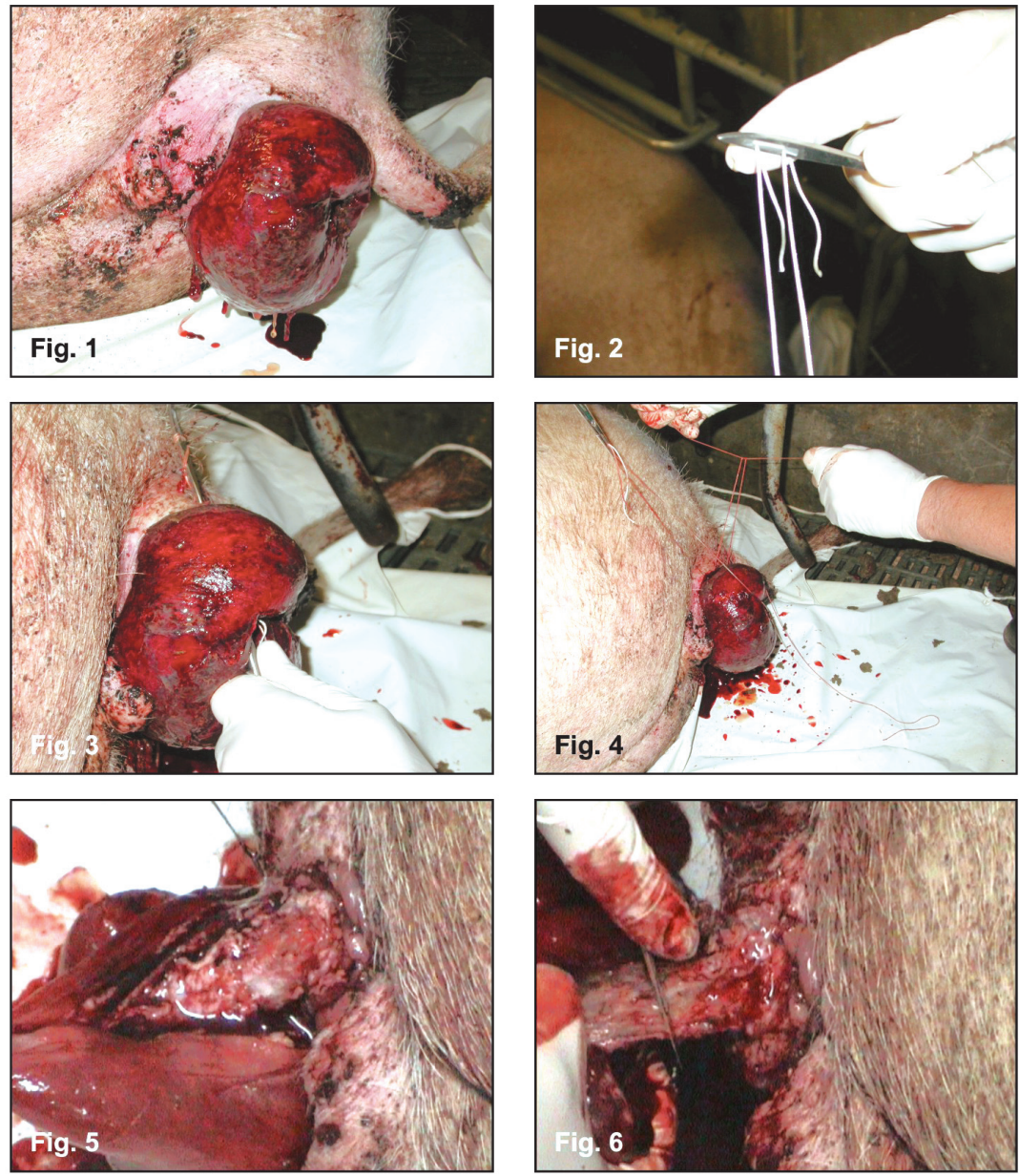

Fig. 1. Rectal prolapse

Fig. 2. Two fibres in the Gerlach's needle

Fig. 3. Perforation of the prolapsed rectum by Gerlach's needle

Fig. 4. The initial stitch

Fig. 5. Beginning of the amputation

Fig. 6. Finishing of the amputation 
Plate XI
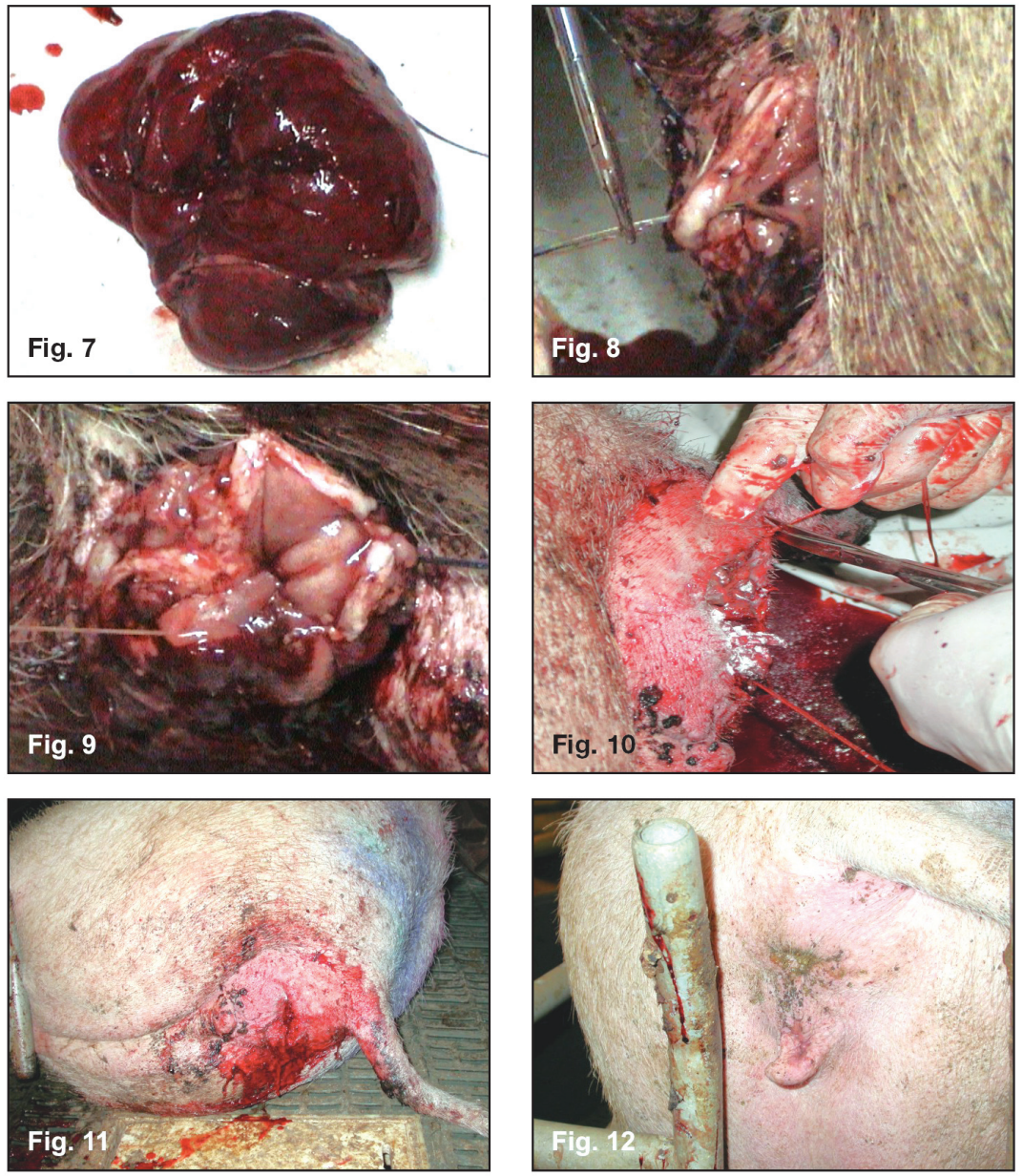

Fig. 7. Resected prolapsed rectum

Fig. 8. Beginning of the continuous suture

Fig. 9. Late stage of the continuous suture

Fig. 10. Cutting of the ligature

Fig. 11. Early retraction of the stump

Fig. 12. Anus 24 after treatment 